International Journal of Engineering Applied Sciences and Technology, 2020

Vol. 5, Issue 4, ISSN No. 2455-2143, Pages 66-72

Published Online August 2020 in IJEAST (http://www.ijeast.com)

\title{
ANALYSIS OF CONSERVATION VOLTAGE REDUCTION (CVR) FACTOR FOR VARIOUS TYPES OF LOADS
}

\author{
Mithila Seva \\ Asset Performance Unit \\ Tenaga Nasional Berhad Research, \\ Selangor Malaysia. \\ Ir. Asnawi Mohd Busrah \\ Asset Performance Unit \\ Tenaga Nasional Berhad Research, \\ Selangor Malaysia. \\ Ir. Yogendra Balasubramaniam \\ Substation Unit \\ Tenaga Nasional Berhad Research, \\ Selangor Malaysia
}

\author{
Khairuddin Abdullah \\ Asset Performance Unit \\ Tenaga Nasional Berhad Research, \\ Selangor Malaysia. \\ Nor Diana Ruszaini Mohd Zin \\ Asset Performance Unit \\ Tenaga Nasional Berhad Research, \\ Selangor Malaysia. \\ Mohd Hafiz Mat Daud \\ Asset Performance Unit \\ Tenaga Nasional Berhad Research, \\ Selangor Malaysia.
}

\author{
Nurul Shuhada binti Pauzai \\ Asset Performance Unit \\ Tenaga Nasional Berhad Research, Selangor Malaysia
}

\begin{abstract}
CVR technique is a common technique that is used for peak reduction and energy saving. The behaviour of loads particularly in distribution system against voltage needs to be assessed to determine the potential benefit of CVR implementation. In the case for residential customers, CVR is more applicable and effective for constant resistance loads. Constant resistance load such as water heater, kettle and microwave equipment has higher CVR factor. Thus, households can benefit from CVR as the reduction in voltage does reduce the power consumed by these equipment. CVR does not only reduce the energy consumed by consumer but also reduces the technical losses of the system. With the reduction in voltage the utility can benefit from the technical losses in the network. The higher the reduction the lower the losses in the system. This study also covers the CVR analysis for electric vehicle $(\mathrm{EV})$ as the demand for $\mathrm{EV}$ is increasing.
\end{abstract}

\section{KeyTerms - CVR. EV and Substation}

\section{INTRODUCTION}

$\mathrm{C}$ ONSERVATION voltage reduction (CVR) and Volt-var Optimization (VVO) are techniques to reduce energy by lowering the voltages on the distribution system in a controlled manner. CVR and VVO can benefit utilities in terms of peak loading relief of the distribution network. However, the reduction in the endpoint voltages (through CVR) reduces the power consumption of certain loads such as resistive loads (incandescent lights) and constant current loads. This helps to achieve both demand reduction and lower distribution circuit losses while having no negative impacts. It is observed that CVR does not reduce the power consumption for all loads such as constant power loads (inverter based power supplies, florescent lights) and heavily loaded motors maintain or even increase power consumption with decreasing voltages.

\section{Guidelines For Manuscript Preparation}

Various power utilities of different countries have executed the CVR and has been proven fruitful. For example Korea Electric Power Corporation (KEPCO) (Shim et al., 2017) tested on 655 Distribution Substation in 2011 by implementing a twostep voltage reduction at $2.5 \%$ and $5.0 \%$ which was used to calculate the maximum demand reduction using the CVRf that led to a reduction of $844 \mathrm{MW}$ and $1660 \mathrm{MW}$, respectively. Electricity North West Limited (ENWL) tested CVR on 4 low voltage (LV) feeders in 2014. This was achieved through a change of the tap settings in the HV/LV transformer. A load reduction of $3.2 \%$ was seen for a $6 \%$ voltage reduction. (More detailed in section III) This is a reduction of power during peak loading and can be used as a tool by network operators to control the power consumption during a crisis. It helps to reduce the strain on the network during peak load periods (Begovic et al., 2000) by managing load profiles and therefore can defer network reinforcement. 


\section{International Journal of Engineering Applied Sciences and Technology, 2020 \\ Vol. 5, Issue 4, ISSN No. 2455-2143, Pages 66-72 \\ Published Online August 2020 in IJEAST (http://www.ijeast.com)}

CVR technique for peak reduction (Erickson and Gilligan, 1982) is well studied by researcher and utilities worldwide. This research project is aimed at assessing the potential of using CVR in reducing energy consumption in the power network which also leads to technical losses reduction.

\section{A. Abbreviations and Acronyms}

CVR - Conservation of Voltage Reduction, TL - Technical Losses, EV - Electric Vehicle, HV - High Voltage and LV Low Voltage

\section{B. Other Recommendations}

This study includes evaluating the potential of CVR techniques in reducing energy consumption and technical losses (Antmann, 2009) in the power network and to formulate methodology and guidelines to identify and select suitable distribution systems for CVR applications to be implemented. The details of this study includes virtual benchmarking study on CVR practices by other utilities, lab measurement shall focus on the equipment and appliances such as air condition, fan, refrigerator, microwave oven, water heater, television, computer, smartphone, LED, compact fluorescent light, fluorescent light (Tang et al., 2018) and many more. Site measurements shall include $11 \mathrm{kV}$ and $\mathrm{LV}$ power distribution network. Finally the development of methodology and guidelines for CVR application to be realized in the near future.

\section{COMPARISON}

\begin{tabular}{|c|c|c|c|}
\hline $\begin{array}{l}\text { Utility and } \\
\text { Criteria }\end{array}$ & $\begin{array}{l}\text { Country } \\
\& \text { Year }\end{array}$ & Methods & Results \\
\hline $\begin{array}{l}\text { Korea } \\
\text { Electric } \\
\text { Power } \\
\text { Corporation } \\
\text { (KEPCO) } \\
\text { (Tested on } \\
655 \\
\text { Distribution } \\
\text { Substation) }\end{array}$ & $\begin{array}{l}\text { Korea } \\
2011\end{array}$ & $\begin{array}{l}\text { Two-step } \\
\text { voltage } \\
\text { reduction at } \\
2.5 \% \text { and } \\
5.0 \% \text {. } \\
\text { It is needed to } \\
\text { calculate the } \\
\text { maximum } \\
\text { demand } \\
\text { reduction at } \\
\text { each CVR } \\
\text { step using the } \\
\text { CVRf. } \\
\text { The } \\
\text { coefficients of } \\
\text { the ZIP model } \\
\text { are assumed } \\
\text { to be } \\
\text { calculated and } \\
\text { assigned to all } \\
\text { substations, } \\
\text { and the } \\
\text { CVRfs are } \\
\text { calculated. }\end{array}$ & $\begin{array}{l}\text { It also } \\
\text { provides the } \\
\text { arithmetic sum } \\
\text { of the load } \\
\text { reduction by } \\
\text { area for } 2.5 \% \\
\text { and } 5.0 \% \\
\text { reduction of } \\
\text { voltage; } 844 \\
\text { MW and } 1660 \\
\text { MW, } \\
\text { respectively. }\end{array}$ \\
\hline
\end{tabular}

\begin{tabular}{|c|c|c|c|}
\hline $\begin{array}{l}\text { Utility and } \\
\text { Criteria }\end{array}$ & $\begin{array}{l}\text { Country } \\
\& \text { Year }\end{array}$ & Methods & Results \\
\hline $\begin{array}{l}\text { Electricity } \\
\text { North West } \\
\text { Limited } \\
\text { (ENWL) } \\
\text { (Tested on } \\
4 \mathrm{LV} \\
\text { feeders) }\end{array}$ & $\begin{array}{l}\text { UK } \\
\text { Published } \\
2014\end{array}$ & $\begin{array}{l}\text { CVR is } \\
\text { realized } \\
\text { through a } \\
\text { reduction in } \\
\text { voltage at the } \\
\text { HV/LV } \\
\text { substation } \\
\text { transformer } \\
\text { for the } \\
\text { purposes of } \\
\text { this study. } \\
\text { This would be } \\
\text { achieved } \\
\text { through a } \\
\text { change to the } \\
\text { tap settings of } \\
\text { the HV/LV } \\
\text { transformer. }\end{array}$ & $\begin{array}{l}\text { Reduction of } \\
\text { load of } 3.2 \% \\
\text { was seen for a } \\
6 \% \text { voltage } \\
\text { reduction. } \\
\text { This is a } \\
\text { material } \\
\text { reduction of } \\
\text { power during } \\
\text { peak times } \\
\text { and can be } \\
\text { used as a tool } \\
\text { by network } \\
\text { operators. } \\
\text { It can help } \\
\text { reduce the } \\
\text { strain on the } \\
\text { network } \\
\text { during peak } \\
\text { load periods } \\
\text { by managing } \\
\text { load profiles } \\
\text { and therefore } \\
\text { defer network } \\
\text { reinforcement. }\end{array}$ \\
\hline $\begin{array}{l}\text { Sacramento } \\
\text { Municipal } \\
\text { Utility } \\
\text { District } \\
\text { (SMUD) } \\
\text { (SMUD } \\
\text { tested at } 14 \\
\text { substations) }\end{array}$ & $\begin{array}{l}\text { USA } \\
2014 \\
\text { (Report) } \\
\text { (EPRI, } \\
\text { 2014) }\end{array}$ & $\begin{array}{l}\text { Utilities } \\
\text { typically } \\
\text { implement } \\
\text { Volt/VAR } \\
\text { management } \\
\text { practices to } \\
\text { achieve } \\
\text { reduction in } \\
\text { either peak } \\
\text { demand. } \\
\text { The peak } \\
\text { demand } \\
\text { reduction } \\
\text { approach is } \\
\text { usually used } \\
\text { to reduce load } \\
\text { for short } \\
\text { durations, } \\
\text { typically for } \\
\text { only a few } \\
\text { hours during } \\
\text { high-demand } \\
\text { or high cost } \\
\text { periods or } \\
\text { both. } \\
\text { The second } \\
\text { approach } \\
\text { CVR, is used } \\
\text { to reduce } \\
\text { energy }\end{array}$ & $\begin{array}{l}\text { Evaluation } \\
\text { was } \\
\text { approximately } \\
0.6, \text { meaning } \\
\text { that for each } 1 \\
\text { percent } \\
\text { reduction in } \\
\text { voltage. } \\
\text { SMUD } \\
\text { realized } 0.6 \\
\text { percent } \\
\text { reduction in } \\
\text { energy/ } \\
\text { demand } \\
\text { during the test. } \\
\text { Average } \\
\text { weekday } \\
\text { energy savings } \\
\text { of } \\
\text { approximately } \\
1.3 \text { to } 1.5 \\
\text { MWh for each } \\
\text { substation- } \\
\text { enough energy } \\
\text { to power } \\
\text { approximately } \\
40 \text { homes. }\end{array}$ \\
\hline
\end{tabular}


International Journal of Engineering Applied Sciences and Technology, 2020

Vol. 5, Issue 4, ISSN No. 2455-2143, Pages 66-72

Published Online August 2020 in IJEAST (http://www.ijeast.com)

\begin{tabular}{|c|c|c|c|}
\hline $\begin{array}{l}\text { Utility and } \\
\text { Criteria }\end{array}$ & $\begin{array}{l}\text { Country } \\
\& \text { Year }\end{array}$ & Methods & Results \\
\hline & & $\begin{array}{l}\text { consumption } \\
\text { for extended } \\
\text { periods. } \\
\text { SMUD } \\
\text { conducted a } \\
\text { year-long } \\
\text { field } \\
\text { demonstration } \\
\text { on multiple } \\
\text { substations to } \\
\text { evaluate both } \\
\text { approaches. }\end{array}$ & \\
\hline
\end{tabular}

\section{METHODOLOGY}

Home appliances (Ahmed, Mohamed and Homod, 2017), office equipment and motor appliances were measured under controlled voltage in the lab where voltage was varied every $5 \mathrm{~V}$ from $215 \mathrm{~V}$ to $250 \mathrm{~V}$ and the power consumption was measured at every voltage change. Equipment that were tested includes air-conditioner (new), air-conditioner (old), CFL light, fluorescent light, incandescent light, LED light, fan, laptop (charging), personal computer, phone, tablet, television (LED), microwave, rice cooker, shower heater, refrigerator and washing machine (Bokhari et al., 2014). Load profile at Pencawang Elektrik (PE) of different load segments, e.g. industrial, commercial and residential were taken using the Fluke 1730 Power Quality recorder. Parameters that were captured include real power $(\mathrm{kW})$, reactive power (KVar) and current (Ampere). Measured data from selected bulk customer and PPU were also obtained. The voltage reduction (Hoseinzadeh, Silva 2015) for a PE however was based on natural occurrences of voltage dip as the testing was performed live and the tempering with the voltage was not allowed to be done. Hence whenever there was a voltage drop, before the tap changer "auto corrects", the power was measured to observe the changes in the power reading during the voltage dip. CVR factor calculation was performed by using KEPCO's method.
The active power CVR factor

$$
C V P_{P}=\frac{\% \Delta P}{\% \Delta V}
$$

The reactive power CVR factor

$$
C V P_{Q}=\frac{\% \Delta Q}{\% \Delta V}
$$

$\% \Delta V=\frac{V_{a f t}-V_{\text {pre }}}{V_{\text {mean }}} \times 100=\frac{\Delta V}{V_{\text {mean }}} \times 100 \%$

$\% \Delta P=\frac{P_{a f t}-P_{\text {pre }}}{P_{\text {mean }}} \times 100=\frac{\Delta P}{P_{\text {mean }}} \times 100 \%$

$\% \Delta Q=\frac{Q_{a f t}-Q_{p r e}}{Q_{\text {mean }}} \times 100=\frac{\Delta Q}{Q_{\text {mean }}} \times 100 \%$

The overall methodology is shown in Figure 1.

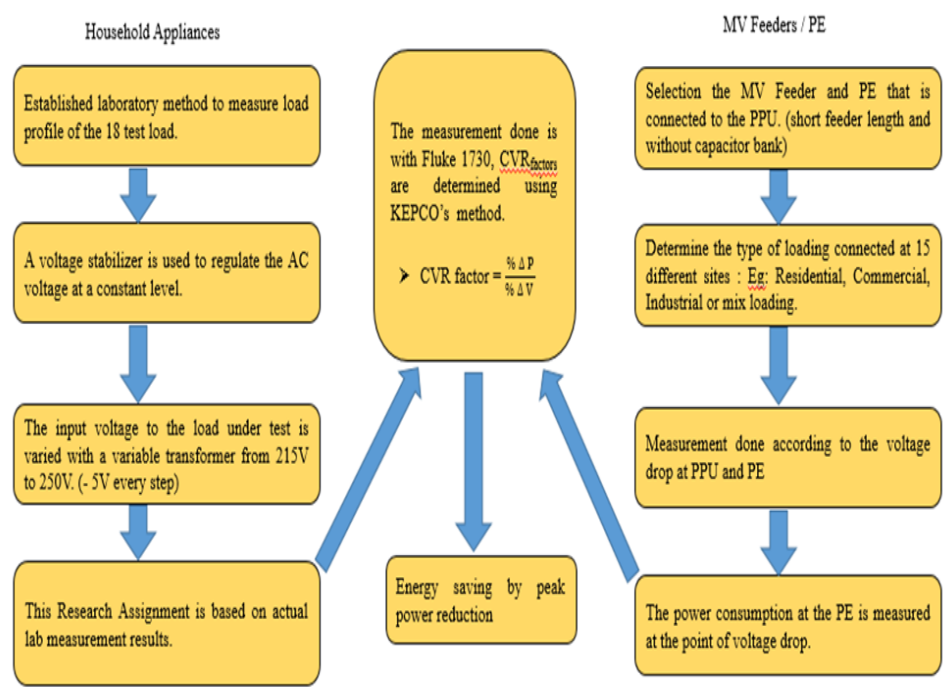

Figure 1: Overall Research Methodology

\section{RESULTS AND DISCUSSION}

\section{A. Household Equipment}

CVR factor for all 18 measured equipment that was measured is shown in Figure 2. The descending CVR factor starting from constant resistance equipment with the highest CVR factor followed by constant current load and constant power load with lower CVR factor. CVR is more effective for constant resistance loads for example heater, microwave, rice cooker and others. The constant power loads are refrigerator, laptop, LED, phone, air conditioner, personal computer and tablet. In this scenario constant power equipment are with the CVR factor lower the 1. Table 1 tabulates the results for the CVR factor for real power. 
International Journal of Engineering Applied Sciences and Technology, 2020

Vol. 5, Issue 4, ISSN No. 2455-2143, Pages 66-72

Published Online August 2020 in IJEAST (http://www.ijeast.com)

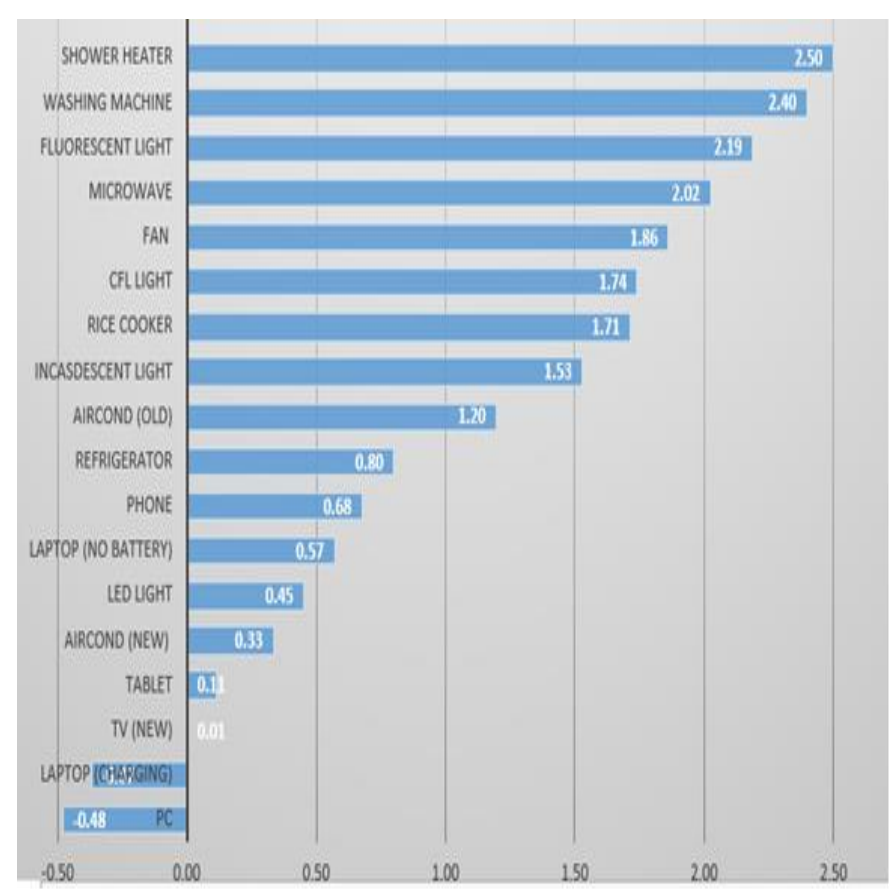

Figure 2: Descending CVR factor for different types of appliances

Table 1: CVR Factor Calculated using Real Power

\begin{tabular}{|c|l|l|}
\hline No & Appliance & CVR $_{\text {factor }}$ \\
\hline 1 & $\begin{array}{l}\text { Aircond (inverter } \\
\text { type) }\end{array}$ & 0.33 \\
\hline 2 & $\begin{array}{l}\text { Aircond (old/non- } \\
\text { inverter) }\end{array}$ & 1.20 \\
\hline 3 & CFL light & 1.74 \\
\hline 4 & Fluorescent light & 2.19 \\
\hline 5 & Incandescent light & 1.53 \\
\hline 6 & LED light & 0.45 \\
\hline 7 & Fan & 1.86 \\
\hline 8 & Laptop (charging) & -0.37 \\
\hline 9 & Laptop (no battery) & 0.57 \\
\hline 10 & PC (Computer) & -0.48 \\
\hline 11 & Tablet & 0.11 \\
\hline 12 & TV (LED) & 0.01 \\
\hline 13 & Microwave & 2.02 \\
\hline 14 & Rice Cooker & 1.71 \\
\hline 15 & Shower Heater & 2.50 \\
\hline 16 & Refrigerator & 0.80 \\
\hline 17 & Washing Machine & 2.397 \\
\hline & & \\
\hline
\end{tabular}

\section{B. Residential, Commercial and Industrial Load}

Many industrial loads are constant power loads hence the voltage reduction will not have an impact to the industrial area. However for residential, there are a variety of mixed load composition hence the residential and small commercial area could apply the voltage reduction thus leading to energy saving with the total energy consumed reduced.

However the results for the industrial load may differ because this is a new developing small medium enterprise (SME) industrial and the utility has not been completely utilized hence that justifies the reading of the CVR factor in the industrial area is a little high. For accuracy purposes, the CVR is calculated at various times which is during the day, evening and night and the average CVR factor is computed. The main reason for this is to ensure that some industrial loads that function at night can also be analysed if if would benefit from CVR. The common pattern for residential and commercial load, is to have the peak during the day and for some industrial loads the peak energy consumed it is at night. Table 2 presents the CVR factor for the real power. Based on the mixed loads perecentage, with the majority as residential loads are considered with an assumption made that it is $100 \%$ residential load. The average is obtained from the 9 residential loads, 1 commercial and 5 industrial loads to calculate the overall CVR factor.

Table 2: Real Power CVR Factor Summary

\begin{tabular}{|c|c|c|c|c|c|}
\hline \multirow{3}{*}{ Load Type } & \multicolumn{3}{|c|}{ CVRf (P) } & \multirow{3}{*}{$\begin{array}{l}\text { CVRf (P) } \\
\text { Average }\end{array}$} & \multirow{3}{*}{$\begin{array}{l}\text { Remarks/Obser } \\
\text { vations }\end{array}$} \\
\hline & Day & Evening & Night & & \\
\hline & $\begin{array}{l}(0800- \\
1700)\end{array}$ & $\begin{array}{c}(1701- \\
2200) \\
\end{array}$ & \begin{tabular}{|c|}
$(2201-$ \\
$0759)$ \\
\end{tabular} & & \\
\hline Residential & 1.021 & 1.448 & 1.150 & 1.206 & \begin{tabular}{|c|} 
Consistent \\
CVRf (P), from \\
1.02 to 1.45. \\
Highest \\
CVRf (P) was \\
recorded during \\
the evening. \\
\end{tabular} \\
\hline Commercial & 0.864 & 1.480 & 1.187 & 1.177 & \begin{tabular}{|c|} 
Slightly low \\
CVRf (P) was \\
observed during \\
the day (0.86). \\
Highest \\
CVRf (P) was \\
recorded during \\
the evening \\
$(1.48)$. \\
\end{tabular} \\
\hline Industrial & NA & 1.219 & 2.429 & 1.824 & $\begin{array}{l}\text { Small Medium } \\
\text { Industry }\end{array}$ \\
\hline
\end{tabular}

Based on the results obtained above the most accurate and reliable results are from the residential loads connected as the commercial and industrial area are still being developed. 


\section{International Journal of Engineering Applied Sciences and Technology, 2020 \\ Vol. 5, Issue 4, ISSN No. 2455-2143, Pages 66-72 \\ Published Online August 2020 in IJEAST (http://www.ijeast.com)}

However some industrial CVR factors are not available (NA) since there was no voltage drop during that period of the day making it not possible to calculate the CVR factor.

\section{Electric Vehicle (EV)}

There are two types of charging point at TNBR namely Chademo and slow charger. Both chargers are connected to the solar photovoltaic panels and charge at $400 \mathrm{~V}$ direct current (DC). CVR for direct current cannot be measured unless the output voltage is varied. However for this Japanese charging set, the user is not able to manipulate the output voltage. Figure 3 shows the schematic block diagram of the EV charger at TNBR. The only option to perform a CVR measurement is to disconnect the solar battery inverters and bypass the battery storage and directly connect to the grid supply for the charging purpose but based on the schematic the charging port will still be in DC. Hence with a DC output performing the CVR analysis is impractical.

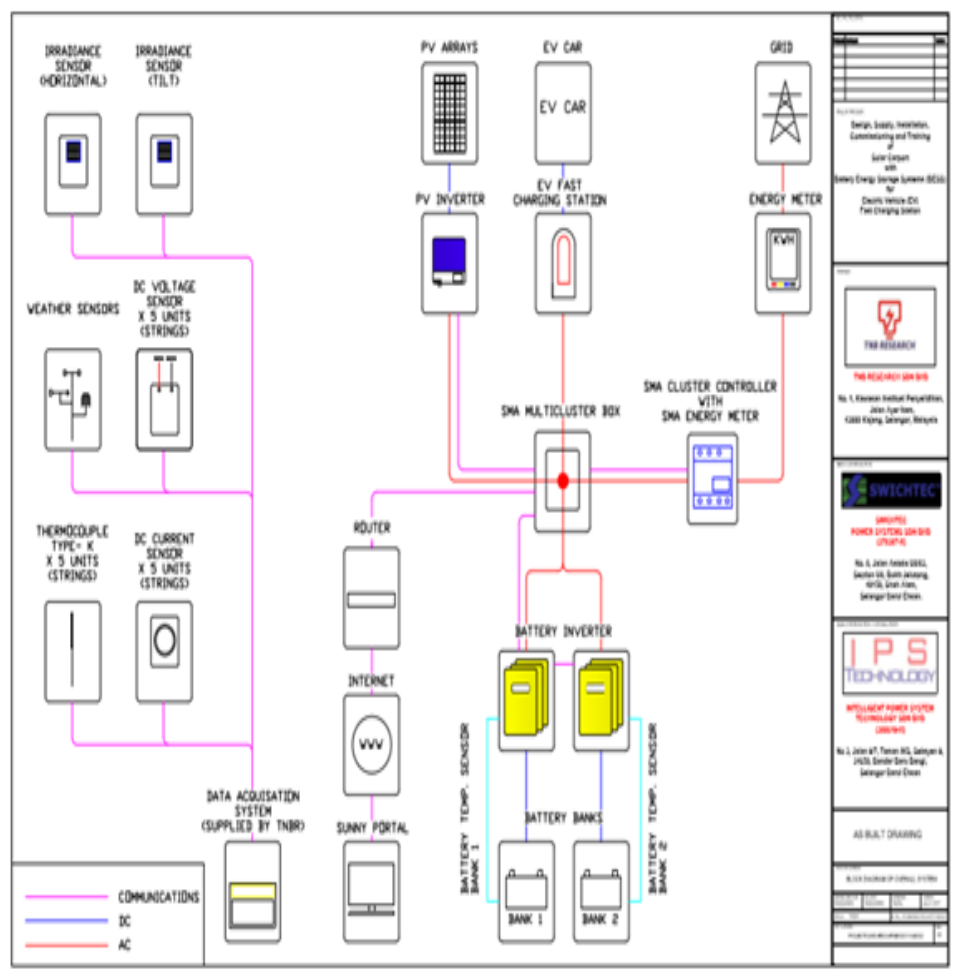

Figure 3: Schematic Block Diagram of the EV

From Figure 3, it can be realised that the EV charging is constant power with the existence of inverters and converters in the system. Therefore it can be concluded that EV charging will not benefit from CVR and it is not viable to perform a CVR study for this system. Further analysis can be performed if the system is able to be manipulated which requires permission from the manufacturer to vary the output of the system.
The CVR and technical losses application was analysed for the increase in voltage. The residential loads measurement was done up to $250 \mathrm{~V}$, with the base voltage as $235 \mathrm{~V}$. The increase in voltage shows that the power consumed will also increase. However using the KEPCO's formula, the change in power and the change in voltage is consistent thus providing the same CVR factor. As for technical losses, based on the simulations done, with the increase in voltage the technical losses remains consistent if the loads are constant and if loads are increased in a substation then the technical losses will increase as well.

\section{CONCLUSION}

CVR factor of lower than 1 shows moderate and values more than 1 implies that the load is feasible to benefit through applying CVR. Values closer to 0 especially for constant power loads will not benefit from the CVR factor where with the reduction of voltage the current drawn is higher to maintain the power value of the equipment. Thus the electricity consumption remains constant.

CVR is more applicable and effective for constant resistance loads. Constant resistance load such as water heater, kettle and microwave equipment has higher CVR factor. Thus, households can benefit from CVR as the reduction in voltage does reduce the power consumed by these equipment. Hence the household bill can be reduced by reducing the voltage to a suitable level. However if a house has many inverter based equipment, then CVR will not be advisable as those are constant power loads. The technical losses was also able to be computed were with the reduction in voltage the technical losses decreases.

Based on the study, residential, commercial and industrial types of loads can benefit from CVR. However for industrial loads (for example: industries that operate heavy machines with constant power motor based equipment) at a smaller ratio as it will have low CVR factors. So the benefit will be very minimal but from the study conducted residential loads will benefit the most from voltage reduction. However additional verification is required to be conducted to further validate these results as the voltage reduction has many factors to be accounted for before a voltage reduction is performed even for a residential load.

\section{REFERENCES}

[1] Ahmed, M. S., Mohamed, A. and Homod, R. Z. (2017) 'AWARENESS ON ENERGY MANAGEMENT IN RESIDENTIAL BUILDINGS : A CASE STUDY IN KAJANG AND PUTRAJAYA', 12(5), pp. 12801294.

[2] Antmann, P. (2009) 'Reducing technical and nontechnical losses in the power sector.', Background Paper for the World Bank Group Energy Sector Strategy, (July 2009), pp. 1-35.

[3] Begovic, M. et al. (2000) 'Impact of distribution 


\section{International Journal of Engineering Applied Sciences and Technology, 2020 \\ Vol. 5, Issue 4, ISSN No. 2455-2143, Pages 66-72 \\ Published Online August 2020 in IJEAST (http://www.ijeast.com)}

efficiency on generation and voltage stability', Proceedings of the Hawaii International Conference on System Sciences, 00(c), p. 98. doi: 10.1109/hicss.2000.926758.

[4] Bokhari, A. et al. (2014) 'Experimental determination of the ZIP coefficients for modern residential, commercial, and industrial loads', IEEE Transactions on Power Delivery, 29(3), pp. 1372-1381. doi: 10.1109/TPWRD.2013.2285096.

[5] EPRI (2014) 'Analysis of Sacramento Municipal Utility District Conservation Voltage Reduction (CVR) Tests', (June). Available at: https://www.epri.com/\#/pages/product/00000000300 2004930/\%0Ahttps://publicdownload.epri.com/Publi cDownload.svc/product=000000003002004930/type $=$ Product.

[6] Erickson, J. C. and Gilligan, S. R. (1982) 'The effects of voltage reduction on distribution circuit loads', IEEE Transactions on Power Apparatus and Systems, PAS-101(7), pp. 2014-2018. doi: 10.1109/TPAS.1982.317449.

[7] Hoseinzadeh, B., Silva, F. M. F. Da and ... (2015) 'Adaptive tuning of frequency thresholds using voltage drop data in decentralized load shedding', IEEE Transactions on ..., 30(4), pp. 2055-2062. Available at: http://ieeexplore.ieee.org/abstract/document/6893056 I.

[8] Shim, K. S. et al. (2017) 'Estimation of conservation voltage reduction factors using measurement data of KEPCO system', Energies, 10(12). doi: 10.3390/en10122148.

[9] Tang, J. H. et al. (2018) 'A statistical method to establish voltage dependency load parameters based on field measurements', International Journal of Electrical and Electronic Engineering and Telecommunications, 7(4), pp. 172-177. doi: 10.18178/ijeetc.7.4.172-177.

[10] T. A. Short and R. W. Mee, "Voltage reduction field trials on distributions circuits," Proc. IEEE Power Eng. Soc. Transm. Distrib. Conf., pp. 1-6, 2012, doi: 10.1109/TDC.2012.6281522.

[11] S. C. Vegunta, D. Hawkins, F. Clifton, A. Steele, and S. A. Reid, "23 rd International Conference on Electricity Distribution DISTRIBUTION NETWORK LOSSES AND REDUCTION OPPORTUNITIES FROM A UK DNO' S PERS PECTIVE 23 rd International Conference on Electricity Distribution Paper 0068 Alternative ( Meshed ) Network
Topology," 23rd Int. Conf. Electr. Distrib., no. June, pp. 15-18, 2015.

[12] Ahmad, N. D. Academy, H. Hussaini, and A. Susan, "Conservation Voltage Reduction ( CVR ) Technique : A Review Conservation Voltage Reduction ( CVR ) Technique : A Review," no. February 2018, 2017.

[13] M. H. K. Tushar and C. Assi, "Volt-VAR Control Through Joint Optimization of Capacitor Bank Switching, Renewable Energy, and Home Appliances," IEEE Trans. Smart Grid, vol. 9, no. 5, pp. 4077-4086, 2018, doi: 10.1109/TSG.2017.2648509.

[14]M. K. AL-Nussairi, R. Bayindir, S. Padmanaban, L. Mihet-Popa, and P. Siano, "Constant power loads (CPL) with Microgrids: Problem definition, stability analysis and compensation techniques," Energies, vol. 10, no. 10, 2017, doi: 10.3390/en10101656.

[15] J. Triplett, "Volt / VAR Control \& CVR How is CVR Supposed to Work ?," pp. 1-31, 2013.

[16] M. Diaz-Aguilo et al., "Field-validated load model for the analysis of CVR in distribution secondary networks: Energy conservation," IEEE Trans. Power Deliv., vol. 28, no. 4, pp. 2428-2436, 2013, doi: 10.1109/TPWRD.2013.2271095.

[17] W. Ellens, A. Berry, and S. West, "A quantification of the energy savings by Conservation Voltage Reduction," 2012 IEEE Int. Conf. Power Syst. Technol. POWERCON 2012, pp. 1-6, 2012, doi: 10.1109/PowerCon.2012.6401391.

[18]N. Markushevich, A. Berman, and R. Nielsen, "Methodologies for assessment of actual field results of distribution Voltage and Var Optimization," Proc. IEEE Power Eng. Soc. Transm. Distrib. Conf., pp. 04, 2012, doi: 10.1109/TDC.2012.6281518.

[19] D. T. Chetty, “THE APPLICATION OF VOLT / VAr OPTIMISATION ON SOUTH AFRICAN DISTRIBUTION POWER NETWORKS Dayahalan Thangavelloo Chetty Declaration - Plagiarism," no. October, 2016.

[20]M. Castro, A. Moon, L. Elner, D. Roberts, and B. Marshall, "The value of conservation voltage reduction to electricity security of supply," Electr. Power Syst. Res., vol. 142, pp. 96-111, 2017, doi: 10.1016/j.epsr.2016.09.006.

[21]P. Antmann, "Reducing technical and non-technical losses in the power sector.," Backgr. Pap. World Bank 


\section{International Journal of Engineering Applied Sciences and Technology, 2020 \\ Vol. 5, Issue 4, ISSN No. 2455-2143, Pages 66-72 \\ Published Online August 2020 in IJEAST (http://www.ijeast.com)}

Gr. Energy Sect. Strateg., no. July 2009, pp. 1-35, 2009.

[22]P. K. Roy, S. P. Ghoshal, and S. S. Thakur, "Optimal VAR control for improvements in voltage profiles and for real power loss minimization using Biogeography Based Optimization," Int. J. Electr. Power Energy Syst., vol. 43, no. 1, pp. 830-838, 2012, doi: 10.1016/j.ijepes.2012.05.032.

[23] T. Fallon and C. Power, "Pre-analysis CVRp $=\% \Delta P$ $\% \Delta \mathrm{V} \mathrm{CVRq}=\% \Delta \mathrm{Q} \% \Delta \mathrm{V}$ Implementation," vol. 5, no. May, pp. 4-7, 2012.

[24]M. Manbachi, H. Farhangi, A. Palizban, and S. Arzanpour, "Smart grid adaptive volt-VAR optimization: Challenges for sustainable future grids," Sustain. Cities Soc., vol. 28, pp. 242-255, 2017, doi: 10.1016/j.scs.2016.09.014.

[25]Z. Wang and J. Wang, "Review on implementation and assessment of conservation voltage reduction," IEEE Trans. Power Syst., vol. 29, no. 3, pp. 13061315, 2014, doi: 10.1109/TPWRS.2013.2288518.

[26] J. C. Erickson and S. R. Gilligan, "The effects of voltage reduction on distribution circuit loads," IEEE Trans. Power Appar. Syst., vol. PAS-101, no. 7, pp. 2014-2018, 1982, doi: 10.1109/TPAS.1982.317449.

[27] "Allocation by Automatic Sectionalizing Switches Operation in Distribution Systems Conservation Voltage Reduction The Development of New Analysis and Measurement of Various Line-to-Ground Phenomena in Transmission and Distribution Systems," no. October, pp. 58-59, 1987.

[28] H. J. Liu, R. Macwan, N. Alexander, and H. Zhu, “A methodology to analyze conservation voltage reduction performance using field test data," 2014 IEEE Int. Conf. Smart Grid Commun. SmartGridComm 2014, pp. 529-534, 2015, doi: 10.1109/SmartGridComm.2014.7007701.

[29] M. Nasri, H. Farhangi, A. Palizban, and M. Moallem, "Multi-agent control system for real-time adaptive VVO/CVR in Smart Substation," 2012 IEEE Electr. Power Energy Conf. EPEC 2012, pp. 1-7, 2012, doi: 10.1109/EPEC.2012.6474950.

[30] T. L. Wilson, "Measurement and verification of distribution voltage optimization results for the IEEE power \& energy society," IEEE PES Gen. Meet. PES 2010, pp. 1-9, 2010, doi: 10.1109/PES.2010.5589762.

[31] K. An, H. J. Liu, H. Zhu, Z. Y. Dong, and K. Hur, "Evaluation of conservation voltage reduction with analytic hierarchy process: A decision support framework in grid operations planning," Energies, vol. 9, no. 12, pp. 8-22, 2016, doi: 10.3390/en9121074.

[32] M. Molinas, D. Moltoni, G. Fascendini, J. A. Suul, and T. Undeland, "Constant power loads in $\mathrm{AC}$ distribution systems: An investigation of stability," IEEE Int. Symp. Ind. Electron., no. June 2014, pp. 1531-1536, 2008, doi: 10.1109/ISIE.2008.4677119.

[33] S. R. Nam, S. H. Kang, J. H. Lee, S. J. Ahn, and J. H. Choi, "Evaluation of the effects of nationwide conservation voltage reduction on peak-load shaving using SOMAS data," Energies, vol. 6, no. 12, pp. 6322-6334, 2013, doi: 10.3390/en6126322.

[34]G. McLorn, S. McLoone, X. Liu, D. J. Morrow, R. Best, and D. Laverty, "Impacts of conservation voltage reduction on customer power quality in future networks," Proc. - 2016 51st Int. Univ. Power Eng. Conf. UPEC 2016, vol. 2017-Janua, no. September, pp. 1-6, 2016, doi: 10.1109/UPEC.2016.8114113.

[35] Y. Che, J. Yang, Y. Zhao, and S. Xue, "Control strategy for inverter air conditioners under demand response," Processes, vol. 7, no. 7, 2019, doi: 10.3390/pr7070407.

[36] V. Alimisis, L. M. Costa, and P. Tordjman, "VoltageVAr optimization (VVO) future trends, challenges and opportunities," 2017 IEEE Power Energy Soc. Innov. Smart Grid Technol. Conf. ISGT 2017, 2017, doi: 10.1109/ISGT.2017.8086000. 